\title{
Performance of locally available bulking agents in Newfoundland and Labrador during bench-scale municipal solid waste composting
}

\author{
Khoshrooz Kazemi, Baiyu Zhang*, Leonard M Lye and Weiyun Lin
}

\begin{abstract}
Background: Newfoundland and Labrador (NL) has one of the highest waste disposal rates in Canada and it has 200 small communities without access to central composting facilities. During Municipal solid waste (MSW) composting, the selection of bulking agents is critical. Bench-scale composting systems plus locally available bulking agents are thus desired for economic and effective MSW management in NL communities. This study evaluated the performance of locally available bulking agents (i.e., NL sawdust and peat) during MSW composting in a bench-scale system. Physiochemical (temperature, oxygen uptake rate, $\mathrm{pH}$, electrical conductivity, moisture and ash content, and $\mathrm{C} / \mathrm{N}$ ratio) and biological (enzyme activities and germination index) parameters were monitored to evaluate compost maturity and stability.

Results: In peat composting, higher temperature for a longer duration was observed, indicating more effective pathogen removal and sterilization. High enzyme activities of dehydrogenase, $\beta$-glucosidase, and phosphodiesterase in the third week of composting imply high microbial activity and high decomposition rate. The low $\mathrm{C} / \mathrm{N}$ ratio for compost product implies acceptable stability states. In sawdust composting, higher temperature and oxygen uptake rate (OUR) were observed in the third week of composting, and higher enzyme activities in the second week. Sawdust composting generated a higher germination index, indicating higher maturity.

Conclusions: Both sawdust and peat are effective bulking agents for the bench-scale composting. The choice of a bulking agent for a particular community depends on the availability of the agent and land in the region, convenience of transportation, price, and the expected quality of the compost product.
\end{abstract}

Keywords: Municipal solid waste (MSW); Bench-scale composting; Sawdust; Peat; Newfoundland and Labrador

\section{Background}

Population growth, aggregation of human settlements, higher living standards, and increased development and consumption of less biodegradable products have increased solid waste generation over the last 20 years (Adhikari et al. 2008; Asase et al. 2009). Municipal Solid Waste (MSW) management has thus become one of the biggest environmental concerns in recent decades (Iqbal et al. 2010). MSW contains high moisture content (60$70 \%)$ and large organic fraction (70-80\%), posing adverse environmental impacts if it is not treated properly. Fortunately, the high organic fraction of MSW can be easily

\footnotetext{
* Correspondence: bzhang@mun.ca

Faculty of Engineering and Applied Science, Memorial University of Newfoundland, St. John's, Newfoundland and Labrador A1B 3X5, Canada
}

converted to energy sources through composting (Jolanun and Towprayoon 2010; Ponsá 2010). Therefore, composting has become an increasingly important strategy for the treatment of MSW. Composting is a biological process in which easily degradable organic matter is stabilized and converted into a humus-rich product by the action of microorganisms (Eiland et al. 2001). The advantages of composting are diverting organic matter from landfills, reducing waste volume, decreasing the potential odour, decreasing the moisture content of MSW, and amending soil/improving soil quality (Haug 1993; Cronje et al. 2003; Arslan et al. 2011; Hasan et al. 2012).

Some environmental conditions (moisture content, aeration rate, $\mathrm{pH}$, and temperature) and substrate characteristics $(\mathrm{C} / \mathrm{N}$ ratio, particle size, bulking agents, nutrients contents, and free air space) affect the composting 
process (Iqbal et al. 2010). Selection of a bulking agent which should be inexpensive and readily available in the vicinity of the composting region is very important because bulking agents can affect the condition of the starting composting mixtures, biodegradation kinetics and composting performance as well as the final compost quality (Blanco and Almendros 1995; Chang and Chen 2010; Jolanun and Towprayoon 2010). Bulking agents have different properties because of their carbon source, physical shape, particle size, water absorption capacity, and their bulking density (Iqbal et al. 2010). Bulking agents are usually fibrous and carbonadoes material with low moisture content; therefore they can absorb part of the leachate produced during decomposition to keep the moisture and sustain the microbial activity (Adhikari et al. 2008; Dias et al. 2010; Iqbal et al. 2010). The bulking agent provides structural support to prevent physical compaction, promotes porosity and air void, and improves the compost aeration and gas exchange (Adhikari et al. 2008; Yañez et al. 2009; Dias et al. 2010; Doublet et al. 2011). It can also act as a buffer against the organic acids in the early stages of composting and help maintain the mixture's $\mathrm{pH}$ within a range from 6-8 for proper microbial activity (Haug 1993), and adjust $\mathrm{C} / \mathrm{N}$ ratio of the feedstock and encourage microbial activity without inhabitation (Jolanun and Towprayoon 2010). Numerous studies have used different bulking agents, which are mostly from agriculture byproducts. They include sawdust (Martin et al. 1993; Blanco and Almendros 1995; Banegas et al. 2007; Adhikari et al. 2008; Chang and Chen 2010; Yang et al. 2013), wheat straw (Blanco and Almendros 1995; Banegas et al. 2007), hay and pine wood shaving (Banegas et al. 2007), bagasse and paper (Adhikari et al. 2008), rice husk and rice barn (Chang and Chen 2010), wooden palette (Huet et al. 2012), cornstalks and spent mushroom substrate (Yang et al. 2013), wheat flour (Silva et al. 2014), peat (Mathur et al. 1986; Mathur et al. 1990; Martin et al. 1993; Vuorinen 2000; Nolan et al. 2011), and barley straw (Vuorinen 2000).

Sawdust is a by-product of cutting, grinding, drilling, and sanding of wood, and it is a very common and easily available bulking agent used in composting to provide the free air space, control moisture, and maintain the $\mathrm{C} / \mathrm{N}$ ratio (Batham et al. 2013). Banegas et al. (2007) mixed aerobic and anaerobic sludge with sawdust in two ratios (1:1 and 1:3 v: v), and concluded that sawdust is a good bulking agent for sludge composting because of its dilution effect on the nutritional components of the compost. Iqbal et al. (2010) suggested that the effect of $40 \%$ addition of sawdust to MSW was best to optimize the moisture content to up to $60 \%$ in composting. Chang and Chen (2010) found more sawdust in the composting mixture resulted in the increase of the water absorption capacity and the composting rate, shorter composting and acidification times, and lower final $\mathrm{pH}$ value.

Peat is an accumulation of partially decayed vegetation or organic matter which has been used as a bulking agent because it has high water absorption capacity, is rich enough in exchangeable $\mathrm{H}^{+}$ions to neutralize the ammonia and the cations released by decomposition prevents the loss of ammonia by remaining slightly acidic environment throughout the composting process. Peat has the capacity for adsorbing anions and retarding the leaching of $\mathrm{NO}_{3}^{-}$and $\mathrm{PO}_{4}^{-3}$ when added to soil. It is fluffy to provide thermal insulation and replaceable air to prevent anaerobic production of malodours, and also has an exceptionally high capacity for enhancing soil organic matter (Mathur et al. 1990).

In Canada, Newfoundland and Labrador (NL) has the highest quantity of waste disposal per capita after Alberta. This amounts to about $429 \mathrm{~kg}$ of residential waste per capita (Statistics Canada 2008). NL comprises more than 200 small communities with population between 100 and 600. Most of these small communities are located in remote and isolated areas and cannot access large solid waste disposal sites or central organic processing facilities. Therefore, on-site composting facilities have been considered as a viable means to deal with organic wastes in the small communities. Although a lack of extensive agricultural production in the northern region of NL could limit the selection of bulking agents for composting, NL generally possesses extensive peat resources. In addition, the forestry industry in NL produces wastes organic materials in the form of sawdust, bark, and wood chips, which can be used as the bulking agent for MSW composting (Martin et al. 1993). The food waste constitutes approximately $40 \%$ of the MSW and it represents a significant proportion of organic material found in MSW. Diversion of food waste from landfill since it is the biggest organic stream in municipal solid waste is essential to reach high diversion target (Environment 2013). Therefore, detailed knowledge of the performance of the composting process with locally available bulking agents would allow the improvement of community-scale composts quality in the small communities of NL.

For compost quality assessment and practical use of composted materials in agriculture, maturity and stability indices are important (Mondini et al. 2004). Stability can be expressed by biological indicators such as the respiration index (i.e., oxygen uptake rate (OUR) or $\mathrm{CO}_{2}$ evolution rate) and enzyme activity (Wu et al. 2000; Benito et al. 2003; Bernal et al. 2009). Important enzymes involved in the composting process include dehydrogenase activity for substrate oxidization by a reduction reaction, $\beta$ - glucosidase activity for glucoside and amide hydrolysis, as well as phosphodiesterase activity for 
phosphate removal from organic compounds (Mondini et al. 2004). Maturity refers to the degree of decomposition where the compost does not pose any adverse effects on plants and growth of various crops (Zmora-Nahum et al. 2005; Castaldi et al. 2008). It is commonly reflected using the germination index (GI). There are currently limited studies on the effect of bulking agents (i.e., peat and sawdust) on the maturity and stability indices such as enzyme activities and GI.

Therefore, in this study, the performance of locally available bulking agents on the bench-scale MSW composting in NL was examined. Meanwhile, a comprehensive investigation of parameters indicating compost maturity and stability and monitoring composting process was conducted. The OUR and enzyme activities were selected to reflect compost stability, and GI was investigated to evaluate compost maturity.

\section{Results and discussion}

\section{Temperature and OUR}

The changes in composting temperature and OUR for FP (food waste + peat) and FS (food waste + sawdust) are shown in Figure 1. The temperature of the composting reactor indicates the breakdown of the organic matter and the quality of the compost, since the rise of temperature is the result of decomposition of readily available organic matter and nitrogen compounds by microorganisms (Ros et al. 2006; Lee et al. 2009). Temperature is one of the important indices to evaluate compost efficiency (Lee et al. 2009) because it affects the biological reaction rate, the population dynamic of microbes, and the physiochemical characteristics of the compost (Hue and Liu 1995). Godden et al. (1983) suggested three distinct stages during composting, including the mesophilic (below $40^{\circ} \mathrm{C}$ ), thermophilic (above $40^{\circ} \mathrm{C}$ ), and cooling (ambient temperature) stage. As the FP composting proceeded, the temperature of the decomposing waste rose rapidly and reached to a maximum temperature of $68^{\circ} \mathrm{C}$ after 2 days.

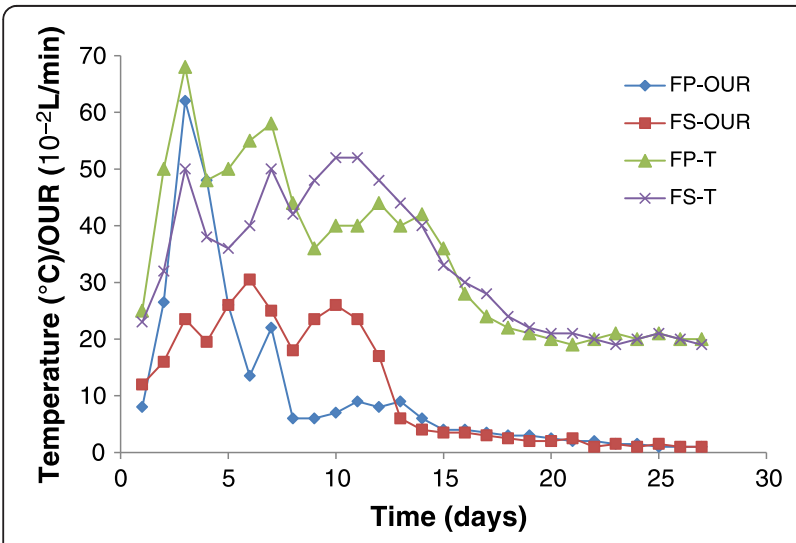

Figure 1 Temporal variations of temperature and OUR.
It is known that the highest thermophilic activity in the composting system was maintained at a temperature between 52 and $60^{\circ} \mathrm{C}$ (Liang et al. 2003; Kalamdhad et al. 2009). The high temperature ensured the elimination of all pathogens; only 3 days at $55^{\circ} \mathrm{C}$ was sufficient for elimination of pathogens (Rasapoor et al. 2009). Although the temperature of the FS compost showed an increase to $52^{\circ} \mathrm{C}$ on the third day, the high temperature period on compost was not sufficient to ensure the hygiene safety of the end product. Longer high temperature period was observed in FP composting, indicating effective pathogen removal and sterilization. The microbial activity and the organic matter breakdown rate decreased when the organic matter became more stabilized and consequently the temperature dropped for almost two weeks in both compost to the ambient temperature (Ros et al. 2006). Microbial respiration has been used to measure the microbial activity during composting. It has also been used to assess the evolution of the composting process and maturity of the final product (Ros et al. 2006). High OUR was recorded for FP during the first 5 days of composting and then it decreased sharply. High OUR indicates that organic matter are available for microorganisms to be degraded, and therefore the material is not stabilized yet. Low OUR indicates organic matter are more stabilized and most of the organic matter has been decomposed by microorganisms (Said-Pullicino et al. 2007). Increase of OUR for FS was smoother and reached the highest value at the end of the first week. Although the maximum OUR for FP was almost double the value of that for FS, the duration of the high OUR was much longer for FS than for FP. The OUR eventually decreased and appear to reach a steady state.

\section{$\mathrm{pH}$ and electrical conductivity (EC)}

The $\mathrm{pH}$ values for FS and FP ranged from 4.6 to 8.68 during composting. The $\mathrm{pH}$ value of the compost is one of the important factors to evaluate compost stability and maturity due to its influence on the physical-chemical and microbiological reactions in the compost (Banegas et al. 2007). The initial $\mathrm{pH}$ and the $\mathrm{pH}$ in the first week of FS and FP composting were slightly acidic as a result of organic acids such as acetic acid and butyric acid, partially contained in the food waste and partially produced by microorganism reactions (Smårs et al. 2002; Adhikari et al. 2009; Eklind and Kirchmann 2000). When microorganisms consume organic acids as a substrate, $\mathrm{pH}$ started to increase (Adhikari et al. 2009). The highest $\mathrm{pH}$ was observed after 8 days for FS and after 16 days for FP compost. This delay for FP compost could be due to the loss of ammonium through volatilization and nitrification, and accumulation of organic acid and $\mathrm{CO}_{2}$ during decomposition of the simple organic matter like carbohydrates (Banegas et al. 2007; Chukwujindu et al. 2006; Kayikçioğlu and 
Okur 2011). Compost with low pH indicates lack of maturity due to the short composting time or occurrence of the anaerobic process (Iglesias Jiménez and Perez Garcia 1989). The final pH for FS and FP was above 8 and $\mathrm{pH}$ levels stayed almost steady by the end of composting.

Compost EC affects microbial population and organic matter transformation. High EC values of compost may have phytoxicity effects on the plant and negatively influence the plant growth and seed germination (Banegas et al. 2007; Kalamdhad et al. 2009; Arslan et al. 2011). Experimental results showed that EC values of FS compost increased earlier than FP compost (Figure 2). This increase could be due to the release of mineral cation concentration such as ammonium ions and phosphate which did not bind to the stable organic complex or went out of the system through leachate (Francou et al. 2005; Kalamdhad et al. 2009).

\section{Moisture and ash content}

Moisture and ash content variations are shown in Figure 3. As shown in the figure, moisture content showed descending trends in both compost. The combination of evaporation because of high temperature and aeration lead to the decrease of moisture content during composting, especially at high temperatures (Said-Pullicino et al. 2007; Lashermes et al. 2012). Moisture content for FS compost showed a slow declining trend by 10 days, which is an indication of decomposition of organic matter (Kalamdhad et al. 2009; Arslan et al. 2011). The temporary increasing trend observed for FS and FP compost was because temperature was not high enough to evaporate the water produced through microbial activity. The amount of ash increased consistently. The ash content increasing trend had a large slope at the thermophilic stage, and then the slope became smoother when the temperature dropped. During composting the organic matter was decomposed into volatile compounds, and consequently

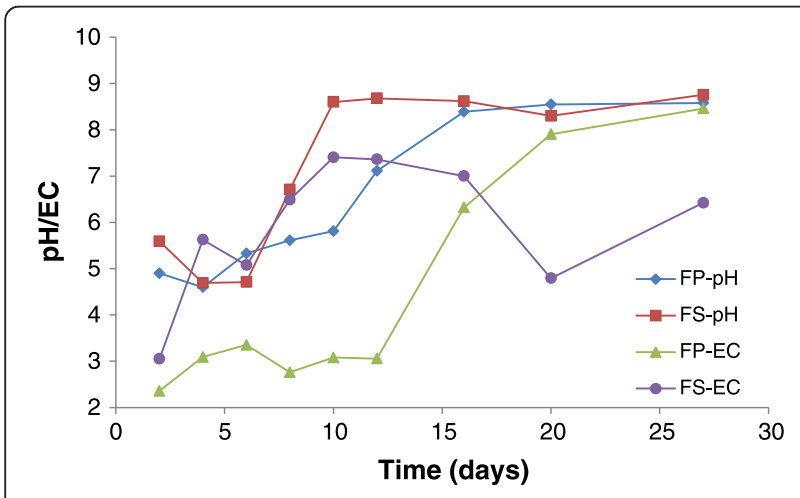

Figure 2 Temporal variations of $\mathrm{pH}$ and EC. the final compost has lower organic matter and higher ash content (Kalamdhad et al. 2009).

\section{$\mathrm{C} / \mathrm{N}$ ratio}

Figure 4 shows the $\mathrm{C} / \mathrm{N}$ ratio variation for both $\mathrm{FS}$ and FP compost. Both composts have close $\mathrm{C} / \mathrm{N}$ ratio in the beginning (17). The initial $\mathrm{C} / \mathrm{N}$ ratio has a strong influence on the performance of the composting process and the quality of the end product (Gao et al. 2010). An extremely high $\mathrm{C} / \mathrm{N}$ ratio makes the composting process very slow as there is an excess of degradable substrate and lack of $\mathrm{N}$ for the microorganisms. On the other hand, a very low $\mathrm{C} / \mathrm{N}$ ratio can lead to loss of $\mathrm{N}$ through $\mathrm{NH}_{3}$ volatilization and generate potential odour problem (de Bertoldi Md, Vallini Ge, Pera A, 1983; Gao et al. 2010; Christensen 2011). For FS and FP composting, the initial $\mathrm{C} / \mathrm{N}$ ratio were lower than the optimum value recommended for composting, i.e., 25 to 30 (Haug 1993). $\mathrm{C} / \mathrm{N}$ ratio decreased for both composts during thermophilic phase. Decrease was very fast for FP whereas after the first week, the $\mathrm{C} / \mathrm{N}$ ratio for FP dropped to 9 while it was 13 for FS. High microbial activity and high decomposition of organic matter after two weeks led to a $\mathrm{C} / \mathrm{N}$ ratio decrease in both treatments. The $\mathrm{C} / \mathrm{N}$ ratio stayed steady after two weeks by the end of the experiments for both FS and FP composts. The final value of $\mathrm{C} / \mathrm{N}$ ratio of FP was low than that of FS.

\section{GI}

The maturity of the compost has been evaluated based on chemical parameters correlated with plant response (Bernal et al. 2009; Xiao et al. 2009). Seed germination test helps to evaluate the efficiency of the composting process for plant growth and seed germination (Banegas et al. 2007). As it is shown in Figure 5, GI is high at the beginning since the raw material is synthetic and nontoxic food waste. GI decreased as a result of formation of toxic compounds such as alcohols, phenolic compound, and organic acids during the thermophilic phase as a result of the composting process. This decrease was sharp for FS compost by the end of the first week and after that it started to increase quickly. It has been suggested that a GI over $80 \%$ indicates the absence of phytotoxicities in compost (Tiquia and Tam 1998; Zucconi et al. 1981). At the end of the composting, GI for FS was higher than $80 \%$; but for FP, GI did not reach $40 \%$, which can be associated with the stage of the composting. Higher degree of maturity was found for the FS compost.

\section{Enzyme activities}

Enzymes are responsible for the breakdown of several organic compounds characterised by complex structures, finally generating simple water-soluble compounds (Castaldi et al. 2008). Characterising and quantifying 


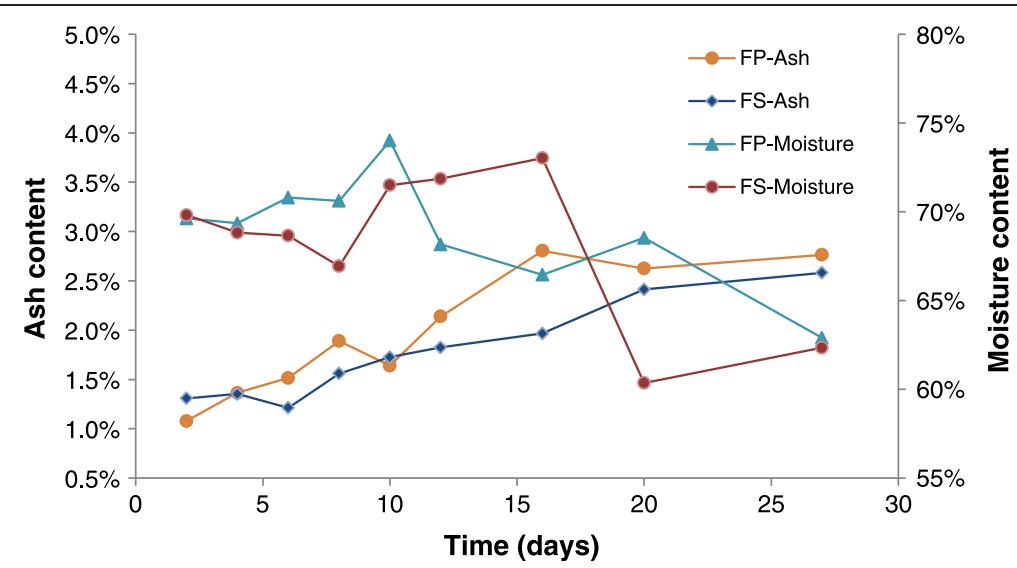

Figure 3 Temporal variations of moisture and ash content.

specific enzyme activities during composting could provide information of dynamics of the composting process. Enzyme activities can reflect the rate of transformation of organic residues and nitrogen, as well as the stability and maturity of end products (Mondini et al. 2004; Raut et al. 2008). Moreover, the determination of enzyme activity, in contrast to other analytical techniques used for compost stability evaluation, is easy, fast, and relatively inexpensive (Mondini et al. 2004). Garcia et al. (1993) confirmed that the hydrolytic enzymes were biomarkers of the state of the composting and evolution of the organic matter.

Dehydrogenase activity was 1,959 and 837 ( $\mu$ g TPF g dry matter $^{-1}$ ) on the second day for FP and FS, respectively. Dehydrogenase is an enzyme belonging to the oxidoreductase group which catalyzes the oxidation of organic substances (Kayikçioğlu and Okur 2011). Bernal et al. (2009) used dehydrogenase activity to monitor the composting process. They concluded that dehydrogenase is a useful parameter to follow the evolution of the biological activity of the composting process, since it correlates well with the temperature profile in the reactor. Dehydrogenase activity increases for FS and FP. FS reached the maximum

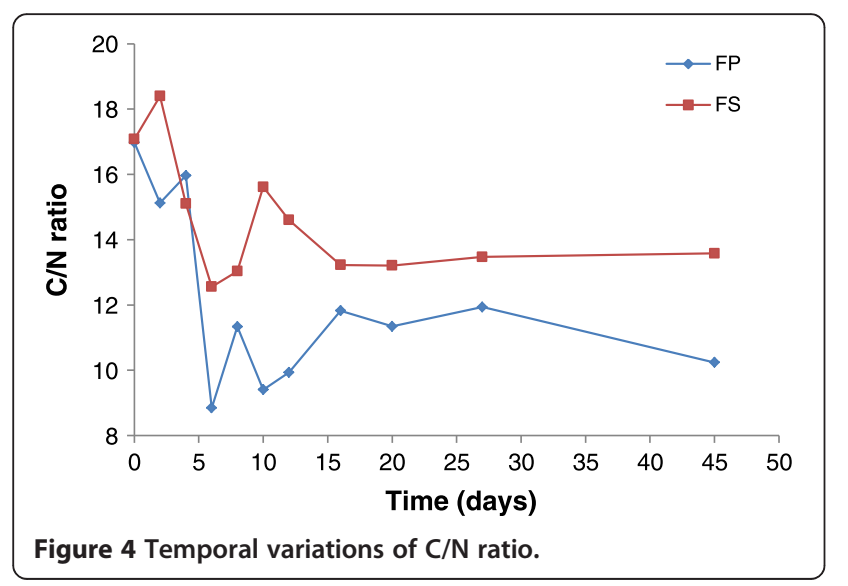

value, 19,106 ( $\mu$ g TPF g dry matter ${ }^{-1}$ ) after 10 days corresponding to the peaks of temperature and OUR. The maximum value, 18,815 ( $\mu \mathrm{g}$ TPF $\mathrm{g}$ dry matter ${ }^{-1}$ ) for FP observed at 16 days at the end of the thermophilic phase or the beginning of the mesophilic stage is similar to the results of Kayikçioğlu and Okur (2011) and Bernal et al. (2009). Vargas-Garcia et al. (2010) stated that the higher dehydrogenase activity values were related to the higher microbial activity and large account of mesophilic and thermophilic bacteria and lower dehydrogenase activity values associated with the maturation phase. The longer period of high dehydrogenase activity was observed for FP compost. As shown in Figure 6, after 20 days the dehydrogenase activity decreased, which means that most of the organic matter has been degraded by the microorganism and converted to stable materials and consequently the respiratory process slowed down (Benitez et al. 1999; Benito et al. 2003; Tiquia 2005; Ros et al. 2006; Vargas-Garcia et al. 2010; Kayikçioğlu and Okur 2011). The cumulative dehydrogenase activity for FP $\left(94,899 \mu \mathrm{g}\right.$ TPF $g$ dry matter $\left.{ }^{-1}\right)$ was much higher than the cumulative dehydrogenase activity for FS $\left(67,924 \mu \mathrm{g}\right.$ TPF g dry matter $\left.{ }^{-1}\right)$.

$\beta$-glucosidase is one of the key enzymes governing the $\mathrm{C}$-cycle. It hydrolyses reducing terminations of b-D-glucose

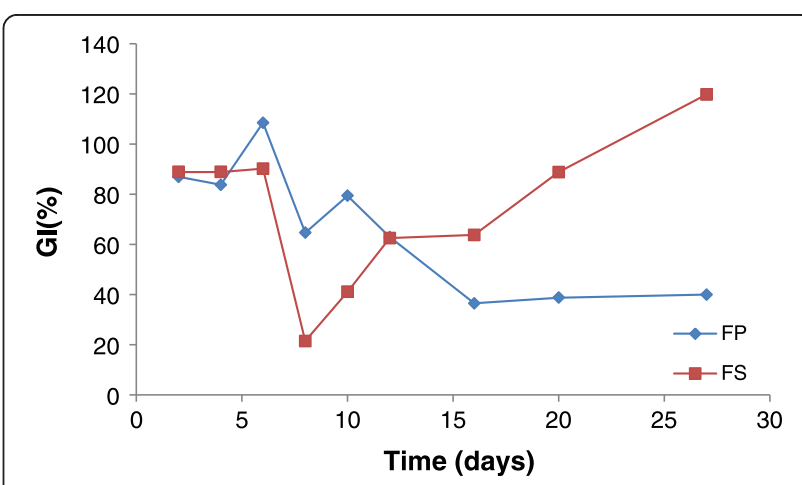

Figure 5 Temporal variations of $\mathrm{Gl}$. 


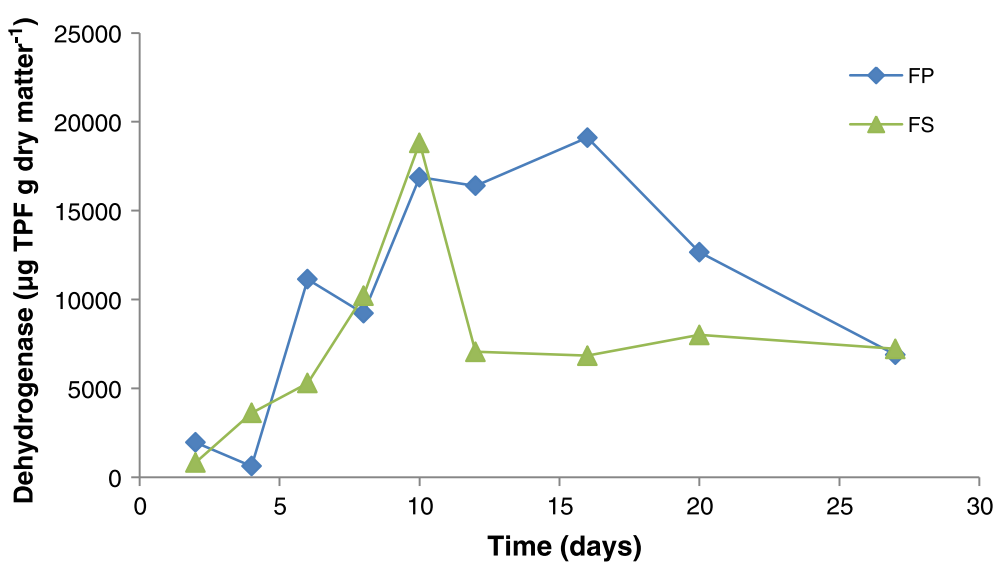

Figure 6 Temporal variations of dehydrogenase activity.

chains and form b-glucose. Its activity is therefore indicative of the presence of these terminations, which come from the labile organic matter (Vargas-Garcia et al. 2010; Kayikçioğlu and Okur 2011). The temporal variation of the $\beta$ - glucosidase activity is shown in Figure 7. $\beta$ - glucosidase activity was high at the beginning for both composts. At the end of the first week, $\beta$ - glucosidase activity showed a peak, 11,980 ( $\mu$ g PNP g dry matt $\mathrm{r}^{-1} h^{-1}$ ), and then dropped. The peak of $\beta$ - glucosidase activity for FS was observed later than for FP after the second week but with almost the same value. $\beta$ - glucosidase activity for both of the composts decreased by the end of composting and it was lower for the FS compost.

Phosphodiesterase (phosphoric diester hydrolases) hydrolyse one or two ester bonds in phosphodiester compounds including nucleases, which catalyze the hydrolysis of phosphodiester bonds of nucleic acids to produce nucleotide units or mononucleotides but not inorganic phosphates. Phosphodiesterase catalyzes phospholipids and nucleic acids degradation which are among the major sources of fresh organic P inputs (Nannipieri et al. 2011). In the beginning, phosphodiesterase activities were high in both composts. Phosphodiesterase activities showed the same trend for FS and FP in the first two weeks. The peak values observed at 8 days, 25,366 and 21,032 ( $\mu$ g PNP g dry matter ${ }^{-1} h^{-1}$ ) for FP and FS, respectively. After 2 weeks, the phosphodiesterase activity dropped dramatically for FS compost and reached zero by the end of the experiment, whereas for FP compost, phosphodiesterase activity was 9,401 ( $\mu$ g PNP g dry matter ${ }^{-1} h^{-1}$ ) at the end of experiment (Figure 8).

\section{Conclusions}

The results of different maturity and stability indices indicated the choice of bulking agents is important for composting performance and the quality of the end product.

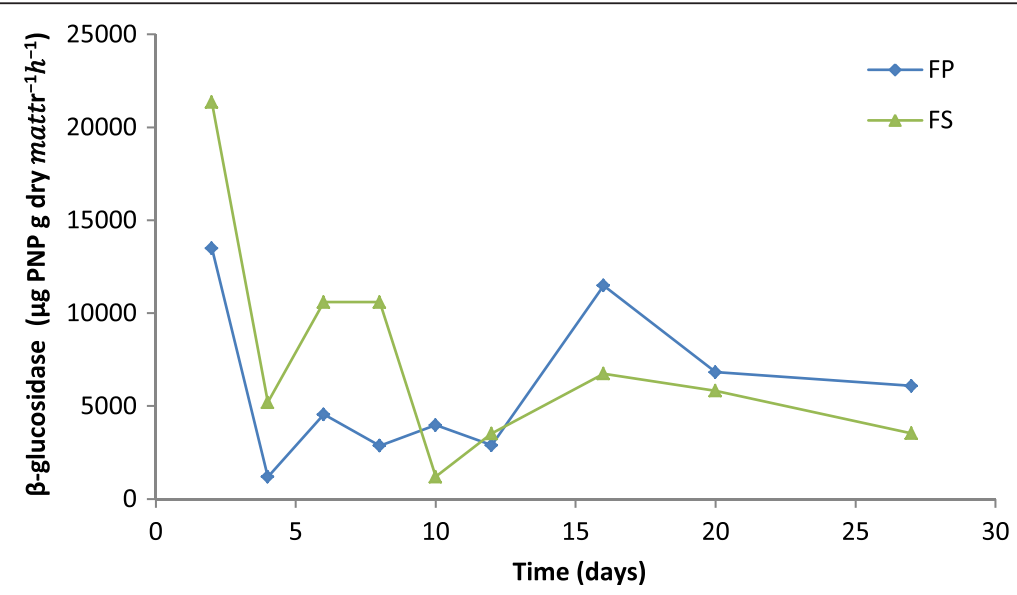

Figure 7 Temporal variations of $\beta$ - glucosidase activity. 


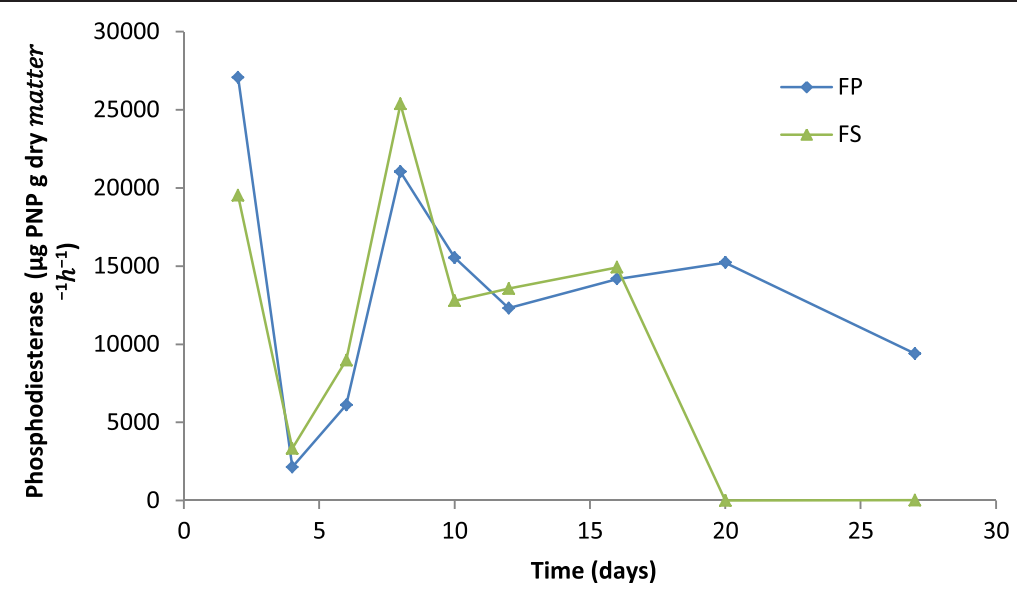

Figure 8 Temporal variations of phosphodiesterase activity.

Applying different bulking agents in composting influence temperature, OUR, GI, dehydrogenase activity and $\beta$-glucosidase activity. The final GI values for food waste composting with sawdust as a bulking agent was found to generate more mature compost with less phytotoxicity. The choice of bulking agent did not affect dehydrogenase and $\beta$ - glucosidase activities values at the end of the composting for both treatments, but the final value for phosphodiesterase activity for FS was much lower than that for FP. High dehydrogenase and $\beta$-glucosidase activities during the third week of composting for FP indicate high microbial activities. To generate a high temperature and a longer duration of high temperature to kill pathogens and sterilize the compost, peat was considerably more effective. Both sawdust and peat are effective bulking agents for bench-scale composting. The choice depends on the availability of the bulking agent and land in the target community, the price of the bulking agent and its transportation, and the desired quality (e.g., higher maturity or stability) of the end compost.

\section{Methods}

\section{Raw materials and experimental system}

The synthetic MSW (food waste) consists of potato, carrot, meat, rice, cabbage, and soybean. The composition of the composting mixture is presented in Table 1. Food material was shredded with food processor to approximately $5 \mathrm{~mm}$ in diameter and was then mixed with locally available sawdust or peat (in a ratio of 10:1 by wet weight) with the moisture content adjusted to $70 \%$. Two mixtures including FP (food waste + peat) and FS (food waste + sawdust) were composted in two identical labscale reactors for a month. Each composting reactor $(50 \times 20 \times 25 \mathrm{~cm})$ was made of acrylic sheets (Figure 9).
Six mixers were installed to enable homogenous materials. A perforated plate was installed over the bottom of reactor to distribute the injected air. The aeration rate was monitored by a flowmeter. The exhaust gas was discharged into a flask containing $\mathrm{H}_{2} \mathrm{SO}_{4}$ solution $(1 \mathrm{M})$ to absorb $\mathrm{NH}_{3}$, and then primarily monitored by gas monitoring system before released through ventilation system. The leachate outlet was used to collect the outcome leachate. A thermometer was used to monitor the temperature. The reactor was cover by heat insulating material to prevent the heat loss.

\section{Sampling and analysis}

Samples were collected randomly from 3-4 different points in the reactors after turning material, and then mixed together in a beaker on the 2nd, 4th, 6th, 8th, 10th, 12th, 16th, 20th, and 27th days. The effect of bulking agent on composting was evaluated through measuring $\mathrm{pH}, \mathrm{EC}$, $\mathrm{C} / \mathrm{N}$ ratio, moisture content, ash content, dehydrogenase activity, phosphodiesterase activity, $\beta$ - glucosidase activity, and GI. Temperature and OUR were recorded every

Table 1 Composition of composting mixtures (unit: kg)

\begin{tabular}{lll}
\hline & FP & FS \\
\hline Meat & 0.3 & 0.3 \\
Rice & 2.2 & 1.9 \\
Carrot & 2.2 & 2 \\
Potato & 1.1 & 1.1 \\
Lettuce & 0.2 & 0.2 \\
Soybean & 0.3 & 0.8 \\
Peat & 0.7 & - \\
Sawdust & - & 0.7 \\
\hline
\end{tabular}




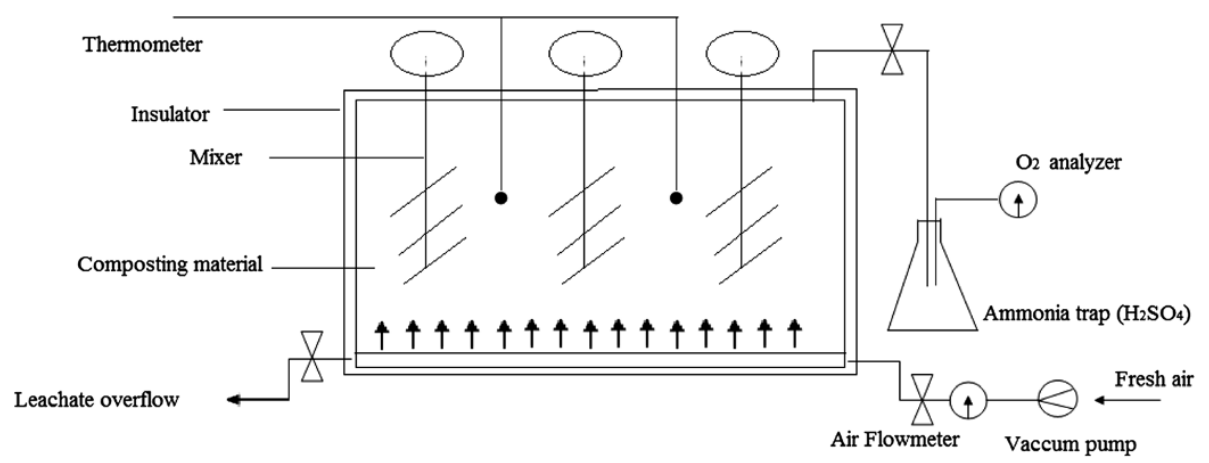

Figure 9 Schematic diagram of the composting system.

12 hours and all parameters were measured in duplicate. The average value for each duplicate measurement was used in figures and tables.

Temperature was recorded by bi-metal dial thermometer ( $\mathrm{H}-\mathrm{B}$ Instrument Company, $\mathrm{PA})$. $\mathrm{EC}$ and $\mathrm{pH}$ were measured in 1:2 (w:v) aqueous extract by using a $\mathrm{pH} / \mathrm{Ion}$ meter (Metller Toledo. EL20-Educational line pH, EL3Educational line conductivity). The moisture content was determined by gravimetric loss on-ignition of $10 \mathrm{~g}$ sample at $105^{\circ} \mathrm{C}$ for $24 \mathrm{~h}$, and the ash content of the dried samples after measuring moisture were determined by burning at $550^{\circ} \mathrm{C}$ in a muffle furnace (Blue $\mathrm{M}$ Electric Company, Blue Island, USA) for $4 \mathrm{~h}$. The outlet oxygen concentration in the compost exhaust gas was monitored by passing the air through a M40 Multi-Gas Monitor (Industrial Scientific Corp., Oakdale, PA, USA). OUR was calculated through the following equation:

$$
\text { OUR }=\left(\left(O_{2} \text { out }(\%)-O_{2} \text { in }(\%)\right) \times \text { airflow rate }(\mathrm{L} / \mathrm{min})\right.
$$

Where $\mathrm{O}_{2}$ out (\%) is the oxygen concentration in compost exhaust gas and $\mathrm{O}_{2}$ in (\%) is the oxygen concentration in the inlet air $(20.9 \%)$ at airflow rate $(0.5 \mathrm{~L} / \mathrm{min} / \mathrm{kg})$ which is injected to the system.

For seed germination test, water was extracted from the samples by shaking fresh samples with double distilled water $(\mathrm{DDW})$ at solids: DDW $=1: 10(\mathrm{w} / \mathrm{v})$ for $1 \mathrm{~h}$, then suspensions were centrifuged at 3,000 rpm for $20 \mathrm{~min}$ before filtering through Whatman No-1 filter paper. A filter paper was placed in the petri dish and almost 10 milliliter of water extract was introduced into the petri dish. Ten cucumber seed were placed on the filter paper. For control experiments, the DDW was used. The dishes were placed in the oven at $25^{\circ} \mathrm{C}$ in the darkness for 5 days. Test for each sample was run in triplicate. The GI was calculated according to Zucconi et al. (1981):

$$
\begin{aligned}
\mathrm{GI}(\%)= & (\text { Seed germination } \\
& \times \text { Root length of the treatment } \\
& \times 100) /(\text { Seed germination } \\
& \times \text { Root length of the control })
\end{aligned}
$$

The total carbon and nitrogen contents of the composting sample were determined by the Perkin Elmer 2400 Series II CHNS/O analyzer.

For dehydrogenase activity determination, a $5 \mathrm{~g}$ sample was suspended in $5 \mathrm{~mL}$ of $3 \% \mathrm{w} / \mathrm{v} \mathrm{2,} \mathrm{3,} \mathrm{5-triphenyl-}$ tetrazolium chloride (TTC) at $37^{\circ} \mathrm{C}$ for $24 \mathrm{~h}$ in the dark, and then $40 \mathrm{~mL}$ acetone was added and incubated at room temperature for $2 \mathrm{~h}$ in the dark. The suspension was filtered through a glass fiber filter and absorbance was measured at $546 \mathrm{~nm}$ (Thalmann 1968; Alef and Nannipieri 1995). Phosphodiesterase activity was measured using the method of Browman and Tabatabai (1978) and Tabatabai (1994). After the addition of a Tris buffere (pH 8) and Sodium bis-p-nitrophenyl phosphate (Sigma; for phosphodiesterase activity) to $1 \mathrm{~g}$ compost, samples were incubated for $1 \mathrm{~h}$ at $37^{\circ} \mathrm{C}$. The p-nitrophenol released by phosphodiesterase activity was extracted and coloured with calcium chloride and determined spectrophotometrically at $400 \mathrm{~nm}$. For $\beta-$ glucosidase activity measurement, a $1 \mathrm{~g}$ sample was suspended in $0.25 \mathrm{~mL}$ toluene and $4 \mathrm{~mL}$ of MUB (Modified Universal Buffer, $\mathrm{pH}$ 6.0) plus $1 \mathrm{~mL}$ p-nitropenyl- $\beta$-D-glucopyranoside (Sigma; for glucosidase). After incubation for $1 \mathrm{~h}$ at $37^{\circ} \mathrm{C}$, $1 \mathrm{~mL}$ of $0.5 \mathrm{M} \mathrm{CaCl}_{2}$ and $4 \mathrm{~mL}$ Tris buffer $(0.1 \mathrm{M}, \mathrm{pH} 12)$ were added and the suspension was filtered through a glass fiber filter. The release of p- nitrophenol was measured spectrophotometrically at $400 \mathrm{~nm}$ (Eivazi and Tabatabai 1988; Alef and Nannipieri 1995). 
Temperature, OUR, moisture content, ash content, and $\mathrm{C} / \mathrm{N}$ ratio were measured in duplicate. $\mathrm{pH}, \mathrm{EC}, \mathrm{GI}$, and enzyme activities are tested in triplicate. The average value for each duplicate measurement was used in figures and tables.

\section{Abbreviations}

MSW: Municipal solid waste; NL: Newfoundland and Labrador; OUR: Oxygen uptake rate; EC: Electrical conductivity; FP: Food waste + Peat; FS: Food waste + sawdust; Gl: Germination index.

\section{Competing interests}

The authors declare that they have no competing interests.

\section{Authors' contributions}

KK designed and conducted experiments, conducted data analysis, and drafted the manuscript. WL helped with laboratory experiment, manuscript drafting, editing, and refinement. BZ is the PI of the project, provided guidance and technical support throughout the study, and revised the manuscript. LL guided experimental design and revision of the manuscript. All authors read and approved the final manuscript.

\section{Acknowledgments}

This research was funded by the Harris Centre Memorial University of Newfoundland.

\section{Received: 30 April 2014 Accepted: 7 July 2014}

\section{Published: 26 July 2014}

\section{References}

Adhikari BK, Barrington S, Martinez J, King S (2008) Characterization of food waste and bulking agents for composting. Waste Manage 28(5):795-804

Adhikari BK, Barrington S, Martinez J, King S (2009) Effectiveness of three bulking agents for food waste composting. Waste Manage 29(1):197-203

Alef K, Nannipieri P (1995) Methods in applied soil microbiology and biochemistry. Academic, London, UK

Arslan El, Ünlü A, Topal M (2011) Determination of the effect of aeration rate on composting of vegetable-fruit wastes. CLEAN-Soil, Air, Water 39(11):1014-1021

Asase M, Yanful EK, Mensah M, Stanford J, Amponsah S (2009) Comparison of municipal solid waste management systems in Canada and Ghana: a case study of the cities of London, Ontario, and Kumasi, Ghana. Waste Manage 29 (10):2779-2786

Banegas V, Moreno J, Moreno J, Garcia C, Leon G, Hernandez T (2007) Composting anaerobic and aerobic sewage sludges using two proportions of sawdust. Waste Manage 27(10):1317-1327

Batham M, Gupta R, Tiwari A (2013) Implementation of bulking agents in composting: a review. J Bioremediation Biodegradation 4(7):1-3

Benitez E, Nogales R, Elvira C, Masciandaro G, Ceccanti B (1999) Enzyme activitie as indicators of the stabilization of sewage sludges composting with Eisenia foetida. Bioresour Technol 67(3):297-303

Benito M, Masaguer A, Moliner A, Arrigo N, Palma RM (2003) Chemical and microbiological parameters for the characterisation of the stability and maturity of pruning waste compost. Biol Fertility Soils 37(3):184-189

Bernal MP, Alburquerque J, Moral R (2009) Composting of animal manures and chemical criteria for compost maturity assessment. A review. Bioresour Technol 100(22):5444-5453

Blanco M-J, Almendros G (1995) Evaluation of parameters related to chemical and agrobiological qualities of wheat-straw composts including different additives. Bioresour Technol 51(2):125-134

Browman M, Tabatabai M (1978) Phosphodiesterase activity of soils. Soil Sci Soc Am J 42(2):284-290

Castaldi P, Garau G, Melis P (2008) Maturity assessment of compost from municipal solid waste through the study of enzyme activities and water-soluble fractions. Waste Manage 28(3):534-540

Chang Jl, Chen Y (2010) Effects of bulking agents on food waste composting. Bioresour Technol 101(15):5917-5924

Christensen TH (2011) Solid Waste Technology \& Management, vol 2, firstth edn Wiley-Blackwell, West Sussex, UK

Chukwujindu M, Egun A, Emuh F, Isirimah N (2006) Compost maturity evaluation and its significance to agriculture. Pak J Biol Sci 9(15):125-131
Cronje A, Turner C, Williams A, Barker A, Guy S (2003) Composting under controlled conditions. Environ Technol 24(10):1221-1234

De Bertoldi M, Vallini G, Pera A (1983) The biology of composting: a review. Waste Manag Res 1(2):157-176

Dias BO, Silva CA, Higashikawa FS, Roig A, Sánchez-Monedero MA (2010) Use of biochar as bulking agent for the composting of poultry manure: Effect on organic matter degradation and humification. Bioresour Technol 101 (4):1239-1246

Doublet J, Francou C, Poitrenaud M, Houot S (2011) Influence of bulking agents on organic matter evolution during sewage sludge composting: consequences on compost organic matter stability and $\mathrm{N}$ availability. Bioresour Technol 102(2):1298-1307

Eiland F, Klamer M, Lind A-M, Leth M, Bååth E (2001) Influence of initial C/N ratio on chemical and microbial composition during long term composting of straw. Microb Ecol 41(3):272-280

Eivazi F, Tabatabai M (1988) Glucosidases and galactosidases in soils. Soil Biol Biochem 20(5):601-606

Eklind Y, Kirchmann H (2000) Composting and storage of organic household waste with different litter amendments. II: nitrogen turnover and losses. Bioresour Technol 74(2):125-133

Environment Canada (2013) Technical document on Municipal Solid waste Organics processing

Francou C, Poitrenaud M, Houot S (2005) Stabilization of organic matter during composting: Influence of process and feedstocks. Compost Sci Util 13(1):72-83

Gao M, Liang F, Yu A, Li B, Yang L (2010) Evaluation of stability and maturity during forced-aeration composting of chicken manure and sawdust at different C/N ratios. Chemosphere 78(5):614-619

Garcia C, Hernandez T, Costa C, Ceccanti B, Masciandaro G, Ciardi C (1993) A study of biochemical parameters of composted and fresh municipal wastes. Bioresour Technol 44(1):17-23

Godden B, Penninckx M, Piérard A, Lannoye R (1983) Evolution of enzyme activities and microbial populations during composting of cattle manure. Appl Microbiol Biotechnol 17(5):306-310

Hasan K, Sarkar G, Alamgir M, Bari QH, Haedrich G (2012) Study on the quality and stability of compost through a Demo Compost Plant. Waste Manage 32 (11):2046-2055

Haug RT (1993) The practical handbook of compost engineering. Lewis Publishers, Boca Raton, USA

Hue N, Liu J (1995) Predicting compost stability. Compost Sci Util 3(2):8-15

Huet J, Druilhe C, Tremier A, Benoist J-C, Debenest G (2012) The impact of compaction, moisture content, particle size and type of bulking agent on initial physical properties of sludge-bulking agent mixtures before composting. Bioresour Technol 114:428-436

Iglesias Jiménez E, Perez Garcia V (1989) Evaluation of city refuse compost maturity: a review. Biological wastes 27(2):115-142

Iqbal MK, Shafiq T, Ahmed K (2010) Characterization of bulking agents and its effects on physical properties of compost. Bioresour Technol 101(6):1913-1919

Jolanun B, Towprayoon S (2010) Novel bulking agent from clay residue for food waste composting. Bioresour Technol 101(12):4484-4490

Kalamdhad AS, Singh YK, Ali M, Khwairakpam M, Kazmi A (2009) Rotary drum composting of vegetable waste and tree leaves. Bioresour Technol 100 (24):6442-6450

Kayikçioğlu HH, Okur N (2011) Evolution of enzyme activities during composting of tobacco waste. Waste Manage Res 29(11):1124-1133

Lashermes G, Barriuso E, Le Villio-Poitrenaud M, Houot S (2012) Composting in small laboratory pilots: Performance and reproducibility. Waste Manage 32(2):271-277

Lee J, Rahman M, Ra C (2009) Dose effects of Mg and PO < sub $>4</$ sub > sources on the composting of swine manure. J Hazard Mater 169(1):801-807

Liang C, Das K, McClendon R (2003) The influence of temperature and moisture contents regimes on the aerobic microbial activity of a biosolids composting blend. Bioresour Technol 86(2):131-137

Martin A, Evans J, Porter D, Patel T (1993) Comparative effects of peat and sawdust employed as bulking agents in composting. Bioresour Technol 44(1):65-69

Mathur S, Daigle J-Y, Lévesque M, Dinel H (1986) The feasibility of preparing high quality composts from fish scrap and peat with seaweeds or crab scrap. Biol Agric Horticulture 4(1):27-38

Mathur S, Patni N, Levesque M (1990) Static pile, passive aeration composting of manure slurries using peat as a bulking agent. Biological wastes 34(4):323-333

Mondini C, Fornasier F, Sinicco T (2004) Enzymatic activity as a parameter for the characterization of the composting process. Soil Biol Biochem 36(10):1587-1594 
Nannipieri P, Giagnoni L, Landi L, Renella G (2011) Role of phosphatase enzymes in soil. In: Phosphorus in Action. Soil Biology 100:215-243

Nolan T, Troy SM, Healy MG, Kwapinski W, Leahy JJ, Lawlor PG (2011) Characterization of compost produced from separated pig manure and a variety of bulking agents at low initial C/N ratios. Bioresour Technol 102 (14):7131-7138

Ponsá S (2010) Different indices to express biodegradability in organic solid wastes, application to full scale solid waste treatment plant. Universitat Autonoma De Barcelona, Spain

Rasapoor M, Nasrabadi T, Kamali M, Hoveidi H (2009) The effects of aeration rate on generated compost quality, using aerated static pile method. Waste Manage 29(2):570-573

Raut M, Prince William S, Bhattacharyya J, Chakrabarti T, Devotta S (2008) Microbial dynamics and enzyme activities during rapid composting of municipal solid waste-a compost maturity analysis perspective. Bioresour Technol 99(14):6512-6519

Ros M, Garcia C, Hernández T (2006) A full-scale study of treatment of pig slurry by composting: Kinetic changes in chemical and microbial properties. Waste Manage 26(10):1108-1118

Said-Pullicino D, Erriquens FG, Gigliotti G (2007) Changes in the chemical characteristics of water-extractable organic matter during composting and their influence on compost stability and maturity. Bioresour Technol 98 (9):1822-1831

Silva MEF, De Lemos LT, Nunes OC, Cunha-Queda AC (2014) Influence of the composition of the initial mixtures on the chemical composition, physicochemical properties and humic-like substances content of composts. Waste Manage 34(1):21-27

Smårs S, Gustafsson L, Beck-Friis B, Jönsson H (2002) Improvement of the composting time for household waste during an initial low $\mathrm{pH}$ phase by mesophilic temperature control. Bioresour Technol 84(3):237-241

Statistics Canada (2008) Human activity and the environment: annual statistics. Environment Accounts and Statistics Division. http://www.statcan.gc.ca/pub/ 16-201-x/2012000/t001-eng.htm. Accessed May 16, 2014

Tabatabai M (1994) Soil enzymes. Methods of soil analysis: Part 2-Microbiological and biochemical properties (methodsofsoilan2)., pp 775-833

Thalmann A (1968) Zur Methodik der bestimmung der dehydrogenaseaktivität im boden mittels triphenyltetrazoliumchlorid (TTC). Landwirtsch Forsch 21:249-258

Tiquia S (2005) Microbiological parameters as indicators of compost maturity. J Appl Microbiol 99(4):816-828

Tiquia S, Tam N (1998) Elimination of phytotoxicity during co-composting of spent pig-manure sawdust litter and pig sludge. Bioresour Technol 65(1):43-49

Vargas-Garcia M, Suárez-Estrella F, Lopez M, Moreno J (2010) Microbial population dynamics and enzyme activities in composting processes with different starting materials. Waste Manage 30(5):771-778

Vuorinen AH (2000) Effect of the bulking agent on acid and alkaline phosphomonoesterase and $\beta$-D-glucosidase activities during manure composting. Bioresour Technol 75(2):133-138

Wu L, Ma L, Martinez G (2000) Comparison of methods for evaluating stability and maturity of biosolids compost. J Environ Qual 29(2):424-429

Xiao Y, Zeng G-M, Yang Z-H, Shi W-J, Huang C, Fan C-Z, Xu Z-Y (2009) Continuous thermophilic composting (CTC) for rapid biodegradation and maturation of organic municipal solid waste. Bioresour Technol 100(20):4807-4813

Yañez R, Alonso J, Díaz M (2009) Influence of bulking agent on sewage sludge composting process. Bioresour Technol 100(23):5827-5833

Yang F, Li GX, Yang QY, Luo WH (2013) Effect of bulking agents on maturity and gaseous emissions during kitchen waste composting. Chemosphere 93(7):1393-1399

Zmora-Nahum S, Markovitch O, Tarchitzky J, Chen Y (2005) Dissolved organic carbon (DOC) as a parameter of compost maturity. Soil Biol Biochem 37(11):2109-2116

Zucconi F, Pera A, Forte M, De Bertoldi M (1981) Evaluating toxicity of immature compost. Biocycle 22(2):54-57

doi:10.1186/s40068-014-0022-x

Cite this article as: Kazemi et al:: Performance of locally available bulking agents in Newfoundland and Labrador during bench-scale municipal solid waste composting. Environmental Systems Research 2014 3:22.

\section{Submit your manuscript to a SpringerOpen ${ }^{\circ}$ journal and benefit from:}

- Convenient online submission

- Rigorous peer review

- Immediate publication on acceptance

- Open access: articles freely available online

- High visibility within the field

- Retaining the copyright to your article

Submit your next manuscript at $>$ springeropen.com 